\title{
Can multicriteria assessment tools help build trust into organic products?
}

\author{
$\underline{\text { Bernhard Frever }}^{1}, \underline{\text { Jim Bingen }}^{2}$ and Rebecca Paxton ${ }^{1}$
}

\begin{abstract}
In a continuously expanding, globalizing, and industrializing organic market, organic consumers confront increasing complexity in organic product representation, labeling, and information that challenges how they build trust in organic products. We present a conceptual framework to analyze how consumers might build and practice trust in the organic agrifood chain. We asked specifically about the role of multicriteria assessment tools (MCATs) for trust building. We identified three consumer trust types: uninformed trust in labels (type 1); informed trust in extensive information, control, and certification (type 2); and informed and engaged trust in forms of close farmer-consumer relationships (type 3). Three concepts of "reflexivity"-unreflective, reflective, selfreflective - are used to explain how these three consumer trust types are operating. We see MCATs as tools accepted and applied mainly by the informed and reflective type. We further examined how reflexivity about two aspects_ethics and systems thinking-in the context of the organic agrifood chain can affect how people trust. Hedonistic, materialistic-oriented consumers might not care about MCATs to deepen their trust in organic, while anthropocentric-oriented consumers were identified as those applying MCATs; ecocentric and holistic-oriented consumers perceive MCATs more as a confinement that limits their self-reflexive and holistic understanding of organic. Awareness of, and interest in, systems thinking by unreflective and uninformed consumer trust types is rather limited; any MCAT is therefore without relevance. The reflective and informed consumer trust type uses a bundle of systems thinking methodologies, and in this context, MCATs would serve as an orientation. The self-reflective, informed, and engaged consumer trust type applies systems theory to learn how to become independent and to better learn how to protect against power interventions; e.g., from industries into the local agrofood chain system. MCATs might play a role, however, would be seen critically because of the high degree of selfdetermination of this type. The unreflective consumer type will not ask for any governance process or related MCAT because they are not sensitized for any bottom-up processes in the agrofood chain. The reflective consumer, however, appreciates more transparency and participation, and would welcome in this context any MCAT that supports more voice for the consumer. The self-reflective consumer who asks for independence and full voice in creating the relation to farmers would at least develop their own MCAT in collaboration with the processors and farmers. Single, double, and triple loop learning are seen as the learning processes that take place when a consumer engages reflexively in the organic agrifood chain. The uninformed consumer type is a single loop learner not heavily interested in MCATs, while the informed is a double loop learner, where MCAT might be a useful tool, and the triple loop learner is seen as the consumer type being engaged in the agrofood chain and would ideally develop their own MCAT. We conclude that MCATs are not relevant for the uninformed consumer to build trust, while the informed consumer would like to apply a predefined MCAT as a tool that allows proof if they can trust in the organic chain. The informed and engaged consumer mostly would not be interested in predefined MCATs, but in some cases might develop their own together with their partners. Their concept of trust is based mainly on being an active partner in the organic agrofood chain and knowing the system by their own experience and contributions. Further theoretical elaboration and empirical research is needed to validate these conceptual reflections on consumer trust.
\end{abstract}

Key Words: ethics; governance; multicriteria assessment tools; organic farming; reflexivity; reflectivity; systems thinking; trust

\section{BACKGROUND}

Now that organic food products can be imported from almost everywhere and found in big chain discount stores, there is an increasing number of concerns about the reliability or truthfulness of products with the organic label. We argue that instead of "throwing out the organic baby with the bathwater," we should explore the ways in which multicriteria assessment tools (MCATs) can be applied to understanding organic purchasing habits of consumers.

Do we need MCATs in order to identify the "truth" about organic products (c.f. Cunliffe 2003:983)? We start our reflection with the assumption that MCATs can help in making decisions in complex situations and support orientation where trust is lacking and information is limited (Delgado-Ballester et al. 2003, Chang et al. 2006). We argue that MCATs can play different roles depending on how consumers trust and reflect their organic purchasing decisions. We do not refer to a specific MCAT but to such tools in general. Assessment tools are discussed mainly within a farm context (Lampkin 2006, Darnhofer et al. 2009:73, Finnveden et al. 2009, Binder et al. 2010). Læssøe et al. (2012) discuss the different concepts of motivation that should be regarded when developing a MCAT for organic consumers in decision-making and reflexive processes. Our paper can be seen as a contribution to understanding how such instruments could fit into different consumers' engagement in reflexive and learning processes and purchasing decisions.

We approach this topic first by discussing the ways in which consumer purchasing decisions rely on trust. For that we examine the meaning of trust and define organic consumer trust types that were adapted from literature on organic consumer purchasing habits. We use this framework to understand how far MCATs might offer a means of creating more trust and transparency for consumers. More specifically, we identify the ways in which different consumer trust types apply these tools, and we characterize their purchasing decision in more detail. We explore the ways in which different types of reflexivity and trust, respectively, affect how people rely on, or need, MCATs. MCATs can also help in finding a way through the complex ethical dimensions in which the organic agrofood chain is embedded. We ask if MCATs could play a role in strengthening governance that 
would support organic consumers in their purchasing decisions. Finally, we reflect on how MCATs might be useful within specific learning approaches that we assume our trust types are built upon.

\section{TRUST FROM A PERSPECTIVE OF ORGANIC CONSUMERS}

\section{The meaning of trust}

Trust means having a firm belief in the reliability, truth, or ability of someone or something (Smeltzer 1997). Such beliefs emerge through social relationships in different social contexts, also known as social fields of interactions (Luhmann et al. 1979, Luhmann 1989). Where trust exists, there are more opportunities to act, in parallel with the increased complexity of the social system (Luhmann 1989:7). Direct social relationships create nearness (Alrøe and Kristensen 2004), a precondition for particular types of trust. This type of trust emerges in "close" systems (Jalava 2003) that are based on personal relationships. Such trust types permit practices that do not rely on formal control processes that serve to reduce complexity (Luhmann 1989:8, 22, 23). Consequently, when social networks-based trust do not exist, the alternative is to trust labels and the reliability of control systems (Jahn et al. 2005).

\section{Trust in the organic agrofood chain and entry points for} multicriteria assessment tools

Organic agrofood chains can be seen as social fields of interaction (Goodman 2002, Sage 2003). From this perspective, these chains permit more or less social relationships between different actors, and thereby provide differentiated potentials for trust (Jarosz 2000). In practice, regional and local organic agrofood chains offer a potential for personal interrelationships and face-to-face communication (Renting et al. 2003), as well as physical proximity.

But trust in organic products has been decreasing (Jahn et al. 2005) as agrofood chains have become more open, globalized, and complex (Raynolds 2004). These processes reduce the ability of processors, traders, sellers, and consumers to oversee the life cycle of a food product (Aschemann et al. 2007). As a result, organic agrofood chains cannot assure consumers of their ethical and social quality, and thereby, they suffer a loss of consumer trust (Raynolds 2000, Birks 2002, Siderer et al. 2005, Seyfang 2006, Arce 2009). The greater the distance between the actors engaged in production, processing, marketing, and consumption, the more agrofood chains become anonymous and rely on labels and/or control and certification systems that are designed and intended to create trust (Pacione 1997, Birks 2002, Padel and Foster 2005, Vogl et al. 2005, c.f. Fritz and Fischer 2007, Toke and Raghavan 2010). At this point, the MCAT comes into the play as an instrument to bridge the increasing distance between the actors along the agrofood chain.

Consequently, the discourse on organic increasingly focuses on certification protocols and procedures that are designed to "control" and "regulate" (Jahn et al. 2005). Table 1 presents some common arguments driving the demand for greater regulation of the organic agrofood chain which often overpower arguments associated with other trust models. However, product labels, control, and certification systems are not immune to skepticism and questions about their reliability and ability to truthfully reflect organic practices (Janssen and Hamm 2011). On the one hand, these regulations are supposed to be ways to assure trust; on the other hand, they are not person-to-person; therefore, their trust-building capacity is limited. Often, the meaning and functioning of control systems are themselves unclear. Bureaucratic processes and inconsistent application add to, rather than reduce, the system's complexity (Albersmeier et al. 2009). The continuing increase in rating, ranking, controlling, and other audits in the organic sector has led to what Michael Power (Power 1994) described as Audit-Explosion and an "organic AuditSociety" (Power 1997). Bureaucratization transfers responsibility from individuals and groups to governance structures that are often anonymous, hierarchical, and inaccessible to consumers. This raises questions about rethinking individual responsibility and the underlying ethical and socio-political questions regarding how the organic agrofood system could, or should, be organized. This is a second entry point where we assume an increasing demand for MCATs as a learning tool that allows the creation of more trust and transparency for the consumer.

Table 1. Domain-specific causes driving control and certification.

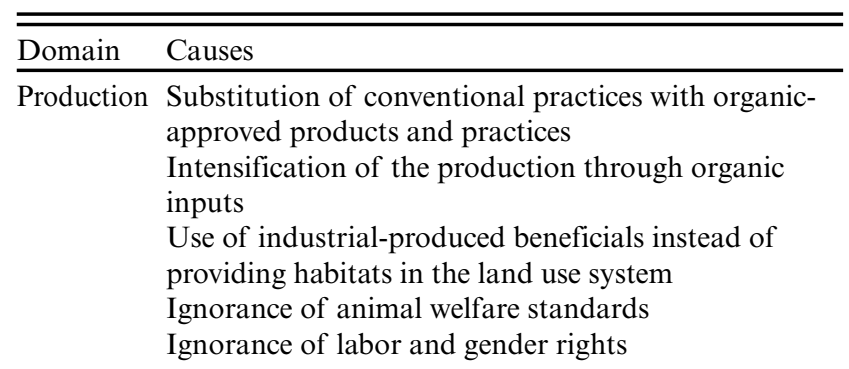

Processing Increased use of not declared or allowed additives Low transparency about the origin of products

Certificat- Economic interests - lobbying through certifiers; e.g., ion at European level Decreasing interest of certifiers in certifying small farms

Shared interests between certifiers and large farms

Consump- Increase in critical consumers concerning the tion ecological and ethical quality of organic products

Trade and Increase in internationally traded products - lack of Market traceability with globalization Consolidation of storage, processing, and selling of products of different origin in one company; risk of wrong declaration

Unfair trade conditions Fulfillment of specific label qualities Marketing strategies in the nonorganic sector, which complicate the differentiation between organic and nonorganic products

A product or process does not fulfill the International Federation of Organic Agriculture Movements standards but is sold as an organic product

Media Misinformation and misinterpretation of the organic idea, organic rules, etc. 


\section{TYPOLOGY OF TRUST}

Based on the literature on consumer motivations, habits, and perceptions related to organic (e.g., Torjusen et al. 2001, Aertsens et al. 2009), we distinguish between three "consumer trust types." Each has three subtypes differentiated by background knowledge of the organic agrofood chain and the basis of trust. Undoubtedly, hybrid forms of the three consumer trust types exist. Finally, we ask about the relevance of MCATs for these types.

Type 1: Uninformed (also: unaware, uninterested) organic consumers: primarily trust the labels (e.g., the aesthetics, forms, colors, symbols).

- Consumers trust the organic label without really knowing what the label means. Purchases based on a label are made by chance rather than from specific knowledge.

- Consumers' beliefs about the trustworthiness of a label are based on the fact that the label is well known and publicly accepted. For these consumers, there is no need to know any further details about the organic agrofood system beyond the label.

- Consumers trust a label in combination with the "face" of an individual (e.g., a farmer or well-known individual) who stands for trustworthiness. Endorsement by such a "trusted person" is the basis of consumer trust in the product.

Type 2: Informed organic consumers: mainly trust (written) information (product and label descriptions, control and certification, tests and assessment instruments, consumer information) about the product.

- Consumers are familiar with the rationale provided by the farmer, company, and label. These arguments describe the qualities of the organic product (e.g., free range eggs, nongenetically modified organisms, grass-fed beef) on the package of a product or in an extra leaflet. Through this information, consumers are persuaded to trust the product.

- Consumers trust a label in combination with certification and control systems. They know about these systems and trust their application.

- Consumers trust the endorsements by authorities for consumer protection and their test reports.

Type 3: Informed and engaged organic consumers: trust their own experiences (e.g., personal communication with farmers, active participation, networking with organic practitioners).

- Consumers trust direct encounters with the farmers (e.g., through farmers' markets or farm visits) that allow the consumers to ask the responsible person directly about the quality of the product. The consumers inform themselves actively and trust farmers' information and their own experiences on the farm.

- Consumers know the specific farmers who produce their food, and therefore do not require a label or knowledge about the production system in order to create trust. Trust comes from the social relationship with the farmer.

- Consumers participate (e.g., in a Community Supported Agriculture scheme or a Participatory Guarantee System), are informed about the production processes, and take responsibility for production and processing practices in the organic agrofood chain.

With respect to MCATs, our question is this: Are there indications of the need for MCATs from different consumer type perspectives? We argue as follows: The uninformed consumers are not interested in detailed information about an organic product: the label is enough to trust. Therefore, MCATs appear to be of little relevance. However, informed consumers are interested in the MCAT: it provides them with more detailed information about the product, which might help them decide if an organic product of interest fulfills their expectations. In contrast, informed and engaged consumers are not really interested in preformulated criteria catalogues like MCATs because they are personally highly involved in the agrofood chain. Based on this involvement, they develop and apply their own tools. For these consumers, trust is a question of knowing the person, or it is an ethical question.

While trust in labels does not require knowledge about organic guidelines (type 1), understanding certification (type 2) or engagement in participatory forms of trust (type 3) demand an extended version of reflexivity. In the following, we identify reflexivity as the key driver beyond these consumer trust types. In the organic context, we argue that ethics and systems thinking that contribute to different types of reflexivity and trust, respectively, affect how people rely on or need MCATs. Furthermore, MCATs could help them to (regain) trust in organic products.

\section{CONCEPTUALIZING REFLEXIVITY}

In this section, we introduce and conceptualize the process of reflexivity as it relates to the formation of trust in the organic agrofood chain. Empirical studies of consumer behavior document the relevance of reflexivity. Several examples of the "reflexive" or "green" consumer are known (Lockie et al. 2002, Lockie and Halpin 2005). Those consumers are well informed via popular media, experts, and personal networks (friends, family). They are concerned about food safety and nutrition (Aertsens et al. 2009) but also the taste of their food (Guthman 2003). In addition, they tend to think and act politically (Hinrichs 2003, DuPuis et al. 2006), and they are locally and collectively oriented in their food choice (Little et al. 2010).

\section{Operationalizing reflexivity}

The literature on reflexivity and reflectivity does not offer a coherent definition and application of the terms (e.g., D'Cruz et al. 2007). As stated by Lynch (2000:47), there are diverse concepts of reflexivity. Sometimes, the definition of the concept overlaps with that of reflectivity, and the two terms are similarly applied, thereby making any attempt to distinguish between them challenging (Schön 1983, Atkins and Murphy 1993, Lynch 2000). In order to apply these concepts, we need to investigate their theoretical foundations and applications in a concrete context.

Reflexivity is a recursive process that, through an ongoing series of actions, operates responses or adjustments in a system (Lynch 2000:27). Through reflexivity, we doubt and rethink the truth claims and representations in which we trust in our social relationships (Clifford 1986). We ask for more transparency and for deeper knowledge based on our own experiences (Hoegl and Parboteeah 2006). Reflexivity involves constantly taking stock of 
personal actions and the role the individual plays in the process (Guillemin and Gillam 2004:274).

\section{Concepts of reflexivity}

White et al. (2006) state in their overview on reflection that it is hard to distinguish between different types of reflection and levels of reflection. They introduce several models that distinguish up to seven levels of reflectivity (King and Kitchener 1994). D'Cruz et al. (2007) discuss the literature about different interpretations of (critical) reflectivity and reflexivity.

Habermas' critical theory (McCarthy 1978) is a guiding typology based on three categories of knowledge (Redmond 2004:13-14): (1) technical, (2) practical, and (3) emancipatory. Technical knowledge refers to problem-solving approaches for assessing and planning, implementing and evaluating. In the foreground are reflections based on scientific evidence, which are referred to "objective knowledge." In our case, MCATs could stand for contributing such knowledge, based on an individual's application of MCATs and reflective processes. Objective knowledge becomes practical knowledge if its application in a particular context is well known. Finally, emancipatory knowledge combines both technical and practical knowledge to produce self-awareness through constructing, deconstructing, confronting, and reconstructing, and representing reflexivity.

Emancipation characterizes the distinction between reflexivity and reflectivity (Lipp 2007). Fay (1987) and Polanyi (1962) describe this progression from technical via practical to emancipatory, which enables liberation from oppression as follows: knowledge with enlightenment (knowing that), empowerment (knowing how), followed by emancipation (knowing why). For Mason (2006:6), reflexivity is about how do I know, and how do I know that I know (Hertz 1997). It is also about looking at a subject from a distant perspective, as suggested by Pierre Bourdieu (Jenkins 1992, Guillemin and Gillam 2004:274): an objective observation of the research subject, and the reflection of the observation itself.

Reflexivity as a practice is not an activity isolated from its social environment. How one is inserted into social networks and power relations shapes reflexivity and influences decisions and interpretations (Sultana 2007:376). It is about what an individual includes or excludes in acting (Guillemin and Gillam 2004:274), and it empowers an individual to trust something. We also see that in the way in which a person reflects, sets their priorities, and is engaged in related practices, expresses a socio-political attitude. This attitude and these activities must be considered as having an impact on socio-political and social developments (Lynch 2000:27).

For the purposes of this discussion, the challenge is to align our three consumer types with different types of reflexivity. Drawing upon several authors, we selected three key concepts of reflexivity (Kember et al. 2000, Stirling 2006:226-229, Voß and Kemp 2006:23, 24):

- Unreflectivity (unreflectiveness) refers to conceptions and interventions that are restricted to the most obvious, instrumental attributes of an option.

- Reflectivity (reflectiveness) is when the full range of attributes and the possibility of unforeseen consequences are taken into account.
- Self-reflectivity is when attention is shifted to include attributes of the actors who do the assessment as constitutive elements of appraisal (see also self-reflectiveness, following Bohmann [1996] in Stirling [2006:227], while Tomm (1987) and Hajer (1996) use the term self-reflexivity) (see The notion of self-reflectivity).

In the following, we introduce these concepts and explain their relationship to the three consumer trust types, as well as the role, status, and relevance of MCATs. These concepts are difficult to observe empirically, and the boundaries between the different types are fluid. In this sense, there is a continuum of reflexivity or of being reflective.

\section{The notion of unreflectivity}

Unreflective is not the opposite of reflective (Lynch 2000:26). Rather, it represents a specific conception of human nature and social reality. We understand this position as one of being not interested in, not prioritizing, and not preferring; i.e., superficial enlightenment (superficially knowing that) (Lipp 2007). In accordance with Lynch (2000:44), it is an argument that it is possible to fail to be reflexive. It is not an expression of a moral virtue of a personality, but it expresses a specific moral within a certain context.

Within the context of our consumer trust types, unreflectivity means "recognizing that there is something," without further or deeper interest in the meaning of the "that." This kind of awareness is similar to that of consumer trust type 1, whose principle reference to organic is the face value of the label. For those consumers, MCATs might be of little interest because for them, the "label" provides them more than enough information about organic. They are explicitly not interested in a deeper reflection process on organic products, and they do not engage with their consumerism into any socio-political context.

\section{The notion of reflectivity}

A reflective person seeks to discover, highlight, structure, and reconstruct a situation by asking what we know, how we know, what we do not know, why we do or do not trust, and what we can or cannot change, and considers methods for understanding different perspectives, beliefs, and values (Fook 2002, Bolton 2010:6). Reflective practice aims to rethink and systematically question current theories, and to end up with new theoretical insights (Osterman and Kottkamp 2004:13-14). Reflectivity is, therefore, empowering; i.e., "knowing how" (Lipp 2007).

This description fits with that of the informed organic consumer trust type. Such consumers understand and interpret the organic standards, seek out explanations in brochures or consumer protection associations, and contextualize written information with the product and their personal values. They also look critically at the organic agrofood chain in relation to social and ethical issues, and are open to social engagements. Those consumers are open to instruments such as MCATs that allow them to systematically structure their decision-making process, and to rethink how to make purchasing choices.

\section{The notion of self-reflectivity}

Many discussions use an understanding of reflexivity in a comprehensive sense, while some apply the term self-reflexivity. Being self-reflective is about our bias-i.e., the blind spot in our thinking (Scott 2004), and the "methodological efforts to root out sources of bias" (Lynch 2000:34). Thus, it is a kind of 
metareflection, a self-criticism (Lynch 2000:30), deepening human experiences (Freshwater and Rolfe 2001:529-530), and reflecting upon our reflection (Scott 2004). This is what Lipp (2007) calls emancipation (knowing why). It is a systemic reflexivity that has its home in reflexive modernization (Beck et al. 2003, Voß and Kemp 2006:28). The reflexive self, as a product of late modernity, focuses on self-improvement and is skeptical about expert knowledge (Lupton 1997).

Self-reflexivity ${ }^{[1]}$ (c.f. Tomm 1987:76) "refers to behavior in which an individual confronts himself in responding to some object and makes an inference about himself as an active self on the basis of that confrontation" (Mead 1934). Self-reflexivity is about reflecting upon my personal acting, and asking if I am fulfilling my personal ethical principles. This entails being critical of the way the self, rather than the environment, is acting. This type of reflexivity represents a constructivist perspective, stating "that we are constantly constructing meaning and social realities as we interact with others and talk about our experience" (Cunliffe 2003:985), a standpoint that is in line with radical reflexivity, questioning any objectification of knowledge (Lynch 2000:36).

The implications of reflexivity itself (what we call self-reflectivity) were outlined by Freshwater and Rolfe (2001): a deeper level of reflection on reflection (type I); taking into account the sociopolitical context (type II); and reflection-in action (type III). Each of these types provides uncertain knowledge (Cunliffe 2003) based partly on lived experiences rather than objective knowledge (Moldaschl 2010:17). The difference is that the individual's lived experiences are contextualized (Ibid:17). Consequently, this experienced-based knowledge invites us to improve knowledge through practice (Ibid:18). Obviously, this concept of reflexivity entails a broader range of characteristics. However, all cited authors agree that the main characteristic is that of deep reflection.

This understanding of reflexivity is congruent with the informed and engaged consumer trust type 3. A MCAT might support such deep reflection processes; however, it could also be of little relevance because a self-reflectivity decision to purchase organic is already done irreversibly (e.g., consumer type 3). It could inspire the self-reflective process, but these consumers-from their holistic perspective and where reflexivity is built on trust by communicating with people-gain their positions primarily directly by interacting with people in the discourse about organic. Moreover, as independent and socio-political motivated consumers, their individual benchmarks are beyond what any MCAT could offer them. A MCAT from their standpoint is more a bureaucratic and static instrument, and not discoursive or flexible enough to respond to the complexity of daily social challenges.

\section{Reflexivity from an ethical and systems perspective}

Being reflexive means applying strategies and techniques that help us question "our own attitudes, thought processes, values, assumptions, prejudices and habitual actions, to strive to understand our complex roles in relation to others" (Bolton 2010:13). This encourages a deeper study and contextualization of the relevance of organic ethical (values) and systems (processes and actions) dimensions in which the consumer is digging for trust.
Awareness of the complexity of ethics in the organic context is raised with the application of systems thinking. Specifically, Alrøe and Kristensen (2003) argued for the foundation of a systemic ethic in organic agriculture. A MCAT appears to be an instrument for initiating reflective processes. It allows the contextualization of ethical attitudes, as well as a systematic description and analysis of many technological, ecological, or economic characteristics of specific product agrofood chains. In the following, we introduce ethical and systems concepts as part of reflexivity and triangulate them with our consumer types and the role of MCATs.

Ethics within concepts of reflexivity

Here we look at organic ethics that are codified in the International Federation of Organic Agriculture Movements (IFOAM) Principles (IFOAM 2009) (Table 2) and which serve as an ethical guide for organic practice (Browne et al. 2000, Lund and Röcklinsberg 2001, Hatanaka et al. 2005). The IFOAM Principles offer a set of mainly eco-centric and holistic ethical positions to guide the development of the organic agriculture movement (Vos 2000, Lund and Röcklinsberg 2001, Alrøe and Kristensen 2002). According to these principles, humans are part of nature and are responsible for the effect of their actions on all living things (Kaltoft 1999, Cohen et al. 2007). The principles provide a precautionary ethical framework for considering responsibility for future generations as well as for partners in the organic agrofood chain as part of current decision-making processes (c.f. Ulrich 1970, Ulrich and Probst 2001).

Table 2. International Federation of Organic Agriculture Movements Principles (Source: Luttikholt 2007).

Principle of Health: Organic agriculture should sustain and enhance the health of soils, plants, animals, humans, and the planet as one and indivisible.

Principle of Ecology: Organic agriculture should be based on living ecological systems and cycles, and should work with them, emulate them, and help sustain them.

Principle of Fairness: Organic agriculture should build on relationships that ensure fairness with regard to the common environment and life opportunities.

Principle of Care: Organic agriculture should be managed in a precautionary and responsible manner to protect the health and well-being of current and future generations and the environment.

The IFOAM ethical principles serve as an orientation for organic practitioners but not as rules that they are obliged to follow. The IFOAM Principles are barely visible in the marketing of products, and as a result, the extent to which organic consumers know about them is questionable (Lea and Worsley 2005, Yiridoe et al. 2005).

Based on this, we assume that organic consumers apply diverse ethical approaches which are expressed in the consumer trust types. Uninformed and unreflective consumers apply a hedonistic, materialistic-oriented ethic in relation to the purchasing of organic products (McEachern and McClean 2002, Meeusen et al. 2003, Aertsens et al. 2009). They are not 
particularly interested in organic or the wider impacts of organic production beyond the product, and do not feel responsible for the impact of their purchasing behavior. They focus mainly on their own health or other personal interests. We are aware that this classification must be applied with care because a lack of interest does not exclude the existence of a broader value set (Lockie 2009). Therefore, this attitude could also represent a pragmatic and practically founded attitude. From that perspective, those consumers would not ask for a MCAT because there is no need for further ethical justification of their purchase.

The informed and reflective organic consumer represents an anthropocentric position which is interested mainly in whether the organic product meets production or technical environmental standards or values such as animal welfare and fair labor conditions (Browne et al. 2000, Lyon 2006). These consumers are predestinated to structure their ethical decision-making process with support of a MCAT. A checklist-e.g., ethical matrixwould support their demand for a decision-making process that is in line with their ethical standpoints. Even IFOAM Principles could be seen as a MCAT; however, ethics cannot be an object of a checklist that is to be fulfilled, similar to a law.

The informed and engaged, as well as self-reflective consumer, stands for an eco-centric and a holistic-oriented ethic (Hjelmar 2011). Eco-centrism means that only ecosystems as a whole can claim moral rights (Schlüns and Voget 2008), whereas holism means that all living and nonliving natural phenomena have a moral right to exist. Both ethics involve fundamental compatibility with the whole organic agrofood chain (Verhoog et al. 2003). On the one hand, this ethical perspective needs instruments to deal with such a complex approach. On the other hand, consumers fear losing the holistic ethical perspective when applying MCATs because those tools always represent a compromise between different stakeholders that are responsible for developing the tool. This critical position is also because MCATs are perceived as a confinement in their self-reflective process.

\section{Systems thinking within concepts of reflexivity}

The organic approach is often studied and reflected within a systems perspective (Hansen et al. 2000, 2001, Bàrberi 2002, Pacini et al. 2004, Noe and Alrøe 2012). In this section, we look at types of systems thinking within concepts of reflexivity with respect to organic agrofood chains (e.g., Guthman 2002). We argue that reflexivity requires systemic organization that brings together different sources of knowledge (Lynch 2000:27, Voß and Kemp 2006:9).

Systems thinking is an umbrella term for a wide range of intellectual traditions (Ackoff 1994:175ff). Three types of systems thinking characterize concepts of reflexivity and provide us with different ways to build trust in the organic agrofood chain: the socio-technical, the social constructivist, and the system dynamics. These three types are described in order to answer the question about how they contribute to better understanding our consumer trust types. Second, we ask if MCATs have any relationship with these different system perspectives.

Socio-technical systems thinking is defined through system elements, subsystems, hierarchies, functions, and flows between the various elements (Von Bertalanffy 1950), and makes a distinction between the system and its environment (Ropohl 1982, Ropohl 1999). Ethical perspectives are included in socio-technical systems thinking through professional ethics and mandatory codices of professions (Lenk and Ropohl 1987, Capurro 1993, Ropohl 1996). The socio-technical systems perspective provides a way of understanding how an organic agrofood chain is constructed and how parts relate to each other. It helps in understanding complex control and certification measures and stimulates the development of alternative modes of control, and with that, of trust. MCATs obviously can support this type of thinking and better understanding of the organic approach, and therefore strengthen trust. This will specifically meet the needs of the reflective consumer, while the unreflective would dread the efforts.

The social constructivist tradition focuses on communication and construction of meaning within a system and between the system and its environment (i.e., structural coupling) (Luhmann 1993). Meaning is reproduced mainly through internal communication and less through communication with its environment (Luhmann 1986, Leydesdorff 2000). Communication in organic agrofood chains, explaining their particularity and distinction from the nonorganic chains, has been well documented (Padel 2001, Jacobson et al. 2003, Demiryurek 2010). In particular, communication in the organic system, in the meaning of Niklas Luhmann, was investigated by Hugo Alrøe and Egon Noe (Alrøe 2000, Noe and Alrøe 2003, 2006, Alrøe and Noe 2008). Here, instead of action, communication is the central element of social systems that delivers meaning, and in our understanding, invites to trust (Giffin 1967). We use communication to interpret the role of MCATs from a social constructivist perspective in two opposing ways. First, a MCAT could help structure communication processes and meaning in the organic system, which finally would help increase trust in market partners and organic products, or as Kastberg (2012) introduced with Sci-Tech communication, as transmission aimed at informing the public. Second, the role of MCATs is of limited relevance because criteria lists do not create trust, but communication and close relationships among people-i.e., farmers and consumers - are required. While the first interpretation guides us toward the reflective consumer, the latter is the basis for the self-reflective consumer who would refuse MCATs.

System dynamics seek to describe and comprehend complexity, nonlinearity, feedback mechanisms (Forrester 1994:245), and systemic interconnections (Voß and Kemp 2006:9). The focus is particularly on the drivers of change, which are characterized by steering and regulating (Milling 1984:4, Forrester 1994). In the organic agrofood chain, system dynamics could help identify feedback mechanisms between production, economy, market, and socio-cultural issues. However, a scientific application of the system dynamics perspective to organic agrofood chains does not currently exist and is an underinvestigated issue in food systems research (Fritz and Schiefer 2008). Applying steering and regulating mechanisms to influence the organic system implies a system target condition, such as that provided by the IFOAM ethical principles (c.f. Ulrich 1970:120, Ulrich and Probst 1991:78ff). Also, system dynamics allow a deeper understanding of the organic agrofood chain, opening the perspective on the high complexity of the organic system. In this case, MCATs can help to better overlook the complex steering and regulating 
mechanisms of the organic system and therefore strengthen trust in organic products. This perspective invites first of all the reflective consumers who always ask for deep understanding of the organic system. It is also of interest to the self-reflective consumer to better understand how to move towards an agrofood system that is localized and independent. But as mentioned, this consumer type prefers its independence from any predefined list of criteria.

\section{THE ROLE OF GOVERNANCE AND LEARNING TYPES}

Thus far we have discussed different types of organic consumer trust and their relationship to concepts of reflexivity and ethics. We have gained insights into individual attitudes and mindsets about how MCATs might be of relevance and would fit in consumers' way of trusting organic products. Looking at the broader social environment of an individual, it is important to ask how trust and reflexivity are a product of societal structures, and how they may initiate societal change. Again, we refer to the MCAT and its role in a governance and learning context.

We extend our analysis to examine how reflexive practices and related consumer trust types help us understand contemporary programs and policy dilemmas in organic. A socio-political attitude is expressed in the way in which a person reflects and sets their priorities and related practices in which they engage. This attitude and these activities, expressed in a certain mode of governance, must be considered as having an impact on sociopolitical and social developments (Lynch 2000:27). In organic agrofood systems, labels and control and certification systems are commonly used to govern (c.f. Bulkeley 2005:175). These governmental policies and procedures, the IFOAM Norms, and modifications from private organizations are used to determine trustworthiness.

The largely passive, uninformed, and unreflective consumer often does not know about these policies. This consumer does not question or challenge governmental policy. Under these conditions, accountability substitutes for responsibility; legal compliance mechanisms that are oriented toward control take precedence over additional ethical reflection (Arjoon 2005:11). This consumer is minimalistic concerning the time invested in detailed background information about organic. Consequently, the unreflective consumer is neither organized nor interested in collaborative consumer activities. In addition, this consumer does not demand any MCAT, thereby allowing more governance.

The reflective consumer takes a critical stance on governmental and large-scale corporate market activities in the context of the conventional (in contrast to participatory guarantee systems) organic control and certification system. The given political and juridical framework is accepted but in contrast to the unreflective consumer with a rather critical ethical perspective; e.g., on social justice. If a MCAT entails any components that are supportive to critically prove personal organic food chains governance qualities, those consumers would welcome such instruments and would help them assess whether they can trust in the organic system. The reflective and informed consumer contributes to creating public opinion but does not directly initiate fundamental change. These organic consumers could be organized in networks acting together but not with the aim of creating structures beyond the given organic market systems.
Self-reflexive consumers claim independence from government or other powerful societal or corporate institutions, and are sensitive to power relations. They initiate not only a dialogue between different stakeholders and interests but often put social innovations at the center of their activities, thus creating social innovation networks (Stirling 2006). This consumer integrates comprehensive systemic knowledge and an ethical perspective, thereby strengthening the trust of stakeholders who participate in the formation of own structures, processes, and rules in social networks (Kooiman and van Vliet 1993:64). This takes place through negotiation, collaborative efforts, and participatory approaches (Folke et al. 2005). MCATs might play a role so far as stakeholders develop their own MCAT, while they do not accept any predefined criteria list. Instead, a MCAT is an outcome of negotiating between different stakeholder groups, which can become the basis for a "memorandum of understanding," not only how to produce or how to fix prices but also for communicating or resolving conflicts between different parties. Alternative control and certification systems-e.g., the participatory guarantee system (Källander 2008) or participatory group certification (Nelson et al. 2010) - provide the framework for self-governing the agrofood system, including all stakeholders along the whole chain (Le Heron 2003, Renard 2005).

Finally, it is important to discuss briefly how we learn to be reflexive and how we can position MCATs. How we reflect is about how we produce knowledge (Kobayashi 2003) and is a precondition for encouraging the consumer to trust via one of these consumer trust types. A well-known model that describes different learning types is "loop" learning (Greenwood 1998). We distinguish between three loop learning processes (Argyris and Schön 1974, Romme and Van Witteloostuijn 1999) and relate them to the concepts of reflexivity and the consumer trust types.

The unreflective consumer engages in a learning process that can be described as the linear single loop learning approach, where values are already accepted (White et al. 2006:13). It involves "learning something," but not specifically reflecting upon what and how is learned. For organic consumers, for example, there is a "knowing that" a label represents organic products, but our unreflective and uninformed consumer trust type does not question what is behind such a label. A MCAT, however, could invite the consumer to become more reflective. Those consumers might be open to engage if there is any animate format that conveys to them any added value if they link with a MCAT, which would allow a starting point for any learning process of the broader meaning beyond organic products.

Reflectivity can be described as double loop learning (Argyris 1976) in which actors rethink their goals and modify their applied methods by asking, "Are we doing the right things?" Double loop learning is seen as a tool of initiating transformative learning processes (White et al. 2006:18) in which people are sensitive to external "triggers" and gradually change their views on the world and themselves (Synnott 2013). The reflective consumer is well informed and refers to technical knowledge, and primarily "knows how" and where they get access to knowledge. This learning approach defines the informed consumer: open to instruments like MCATs that guide a critically reflective perspective on the conditions under which products are produced, processed, and sold, and that follows the overall idea of the 
organic approach presented by the IFOAM Principles. In this context, MCATs could also help as an orientation in the discourse on the further development of organic standards.

Self-reflectivity is represented by triple loop learning approaches (Romme and Van Witteloostuijn 1999). It involves learning how to learn or contextualize cybernetic loop learning (Lynch 2000:27), and is guided by the ethical question: How do we decide what is right? The self-reflective consumer wants to "know why" in a holistic sense. The self-reflective consumer combines practice with technical and practical knowledge. Triple loop learning also includes experimental learning that can be both an individual activity and a social learning process (Wildemeersch et al. 1998). The power, responsibility, and creativity of external or internal partners in participatory systems play a vital role in this learning process. Clearly, the informed and engaged consumer trust type is a triple loop learner. From that perspective, any MCAT could contribute to reflection on the organic approach. However, actors' expectations of such an instrument are high, and in their understanding of learning that is based on self-reflective processes, it will play, in maximum, not more than one input between others to find out their way of acting.

Climbing up the ladder of reflexivity is challenging. Reflexivity is not something that can be planned and arranged by external forces. As with ethics, it requires an individual capacity, often resulting from social interaction (Piaget 1965). Both reflexivity and ethics require individual initiative, learning processes, and individual responsibility (c.f. Schmid 2010). Cunliffe (2003:985) describes his personal process of approaching reflexive practices as "I'm undermining my own position by privileging a particular (reflexive) ontology and epistemology." This is, of course, a challenge to most people, and might reduce motivation for reflective practices.

\section{CONCLUSIONS AND NEXT STEPS}

We applied the concept of reflexivity to help understand how consumers build and shape trust in the organic agrofood chain. Furthermore, we reflected on what role MCATs might play for different consumer types and their type of reflexive processes. Based on a literature review, we conceptualized three consumer trust types in which each comprises three variants (subtypes) based on particular characteristics of trust and knowledge generation. The literature on reflexivity was reviewed and three concepts of reflexivity were defined and related to our three consumer trust types. To deepen the concept of reflexivity, we specifically looked at the significance of ethics and systems thinking in the organic agrofood chain (Table 3). Governance was introduced to help explain consumer trust and the socio-political dimension of reflexivity. Finally, loop learning approaches were discussed in order to illustrate how reflexivity is motivated and practiced.

Consequently, we can distinguish three consumer trust types that are built on concepts of reflexivity, modes of governance, and learning approaches. Together, trust, reflexivity, and governance and learning approaches create a logical relationship. Combinations of characteristics from different types (mixed characteristics) or hybrids are possible. However, in general, each consumer trust type represents a characteristic and consistent structure. We think that MCATs are of importance; however, their use varies by consumer type, their reflexivity, understanding of governance, and modes of learning; therefore, they will have different relevance.

Table 3. Defining the continuum of reflexivity within the context of organic consumer trust types.

\begin{tabular}{lccc}
\hline \hline Paradigm & $\begin{array}{c}\text { Cognitive } \\
\text { concepts }\end{array}$ & $\begin{array}{c}\text { Concept of } \\
\text { responsibility }\end{array}$ & $\begin{array}{c}\text { Regulative } \\
\text { strategies }\end{array}$ \\
\hline $\begin{array}{l}\text { Linear } \\
\text { thinking }\end{array}$ & $\begin{array}{c}\text { Independent } \\
\text { norms, rules, } \\
\text { laws }\end{array}$ & $\begin{array}{c}\text { Delegated to an } \\
\text { institution, } \\
\text { externalized, top } \\
\text { down }\end{array}$ & $\begin{array}{c}\text { Hierarchical, } \\
\text { corporate }\end{array}$ \\
$\begin{array}{c}\text { Systemic } \\
\text { thinking }\end{array}$ & $\begin{array}{c}\text { Ethics, systems } \\
\text { learning and } \\
\text { thinking, } \\
\text { governance }\end{array}$ & $\begin{array}{c}\text { Shared by the } \\
\text { owners, } \\
\text { internalized, } \\
\text { bottom up }\end{array}$ & $\begin{array}{c}\text { Heterarchical, } \\
\text { collaborative }\end{array}$ \\
& & & \\
\hline
\end{tabular}

We are aware that the trust characteristics applied are not exhaustive. In further developing this typology, we recommend integrating emotions and empathy to explore how they affect trust of organic products (Verhoef 2005, Aertsens et al. 2009, Briz and Ward 2009, Mondelaers et al. 2009). Thus far, we have addressed this issue only indirectly with respect to the role of face-to-face communication or advertising via labels. MCATs can be seen in this context as a step forward to make organic more transparent, and to learn about the systemic and complex character of organic. MCATs are also specifically of interest in situations where consumers doubt, to help them differentiate if their doubts are eligible or not. Others might criticize MCATs as another instrument that bureaucratizes organic and are nothing more than top-down paperwork. Currently, our analysis comes to the conclusion that MCATs fit into the system of the reflective consumer. From an educational and ethical point of view, it might be an interesting question how unreflective or nonorganic consumers could be attracted by an organic MCAT. Following Niklas Luhmanns' understanding of systems self-reproduction, to influence systems - i.e., the purchasing habits of a nonorganic or unreflective organic consumer, making them aware and open to organic by using MCATs - is challenging and only possible, for example, through structural coupling (Luhmann 2011:6). A hypothesis could be that the reflective nonorganic consumer might be more open to MCATs than the unreflective organic. Finally, empirical studies would be required to examine the applicability of our typology and our reflections about MCATs in practice.

Responses to this article can be read online at: http://www.ecologyandsociety.org/issues/responses. $\mathrm{php} / 6793$

\section{Acknowledgments:}

We thank the editor and the reviewers for their critical and inspiring commentaries, which helped us identify weaknesses and make the paper more concrete. 


\section{LITERATURE CITED}

Ackoff, R. L. 1994. Systems thinking and thinking systems. System Dynamics Review 10(2-3):175-188. http://dx.doi. org/10.1002/sdr.4260100206

Aertsens, J., W. Verbeke, K. Mondelaers, and G. Van Huylenbroeck. 2009. Personal determinants of organic food consumption: a review. British Food Journal 111(10):1140-1167. http://dx.doi.org/10.1108/00070700910992961

Albersmeier, F., H. Schulze, G. Jahn, and A. Spiller. 2009. The reliability of third-party certification in the food chain: from checklists to risk-oriented auditing. Food Control 20(10):927-935. http://dx.doi.org/10.1016/j.foodcont.2009.01.010

Alrøe, H. 2000. Science as systems learning: some reflections on the cognitive and communicational aspects of science. Cybernetics \& Human Knowing 7(4):57-78.

Alrøe, H. F., and E. S. Kristensen. 2002. Towards a systemic research methodology in agriculture: rethinking the role of values in science. Agriculture and Human Values 19(1):3-23. http://dx. doi.org/10.1023/A:1015040009300

Alrøe, H. F., and E. S. Kristensen. 2003. Toward a systemic ethic: in search of an ethical basis for sustainability and precaution. Environmental Ethics 25(1):59-78.

Alrøe, H. F., and E. S. Kristensen. 2004. Why have basic principles for organic agriculture? and what kind of principles should they be? Ecology \& Farming 27-30.

Alrøe, H. F., and E. Noe. 2008. What makes organic agriculture move: protest, meaning or market? A polyocular approach to the dynamics and governance of organic agriculture. International Journal of Agricultural Resources, Governance and Ecology 7(1):522. http://dx.doi.org/10.1504/IJARGE.2008.016976

Arce, A. 2009. Living in times of solidarity: fair trade and the fractured life worlds of Guatemalan coffee farmers. Journal of International Development 21(7):1031-1041. http://dx.doi. org/10.1002/jid.1634

Argyris, C. 1976. Single-loop and double-loop models in research on decision making. Administrative Science Quarterly 21(3):363375. http://dx.doi.org/10.2307/2391848

Argyris, C., and D. A. Schön. 1974. Theory in practice: increasing professional effectiveness. Jossey-Bass Inc., San Francisco, California. USA.

Arjoon, S. 2005. Corporate governance: an ethical perspective. Journal of Business Ethics 61(4):343-352. http://dx.doi. org/10.1007/s10551-005-7888-5

Aschemann, J., U. Hamm, S. Naspetti, and R. Zanoli. 2007. The organic market. Pages 123-151 in W. Lockeretz, editor. Organic farming: an international history. CAB eBooks.http://dx.doi. org/10.1079/9780851998336.0123

Atkins, S., and K. Murphy. 1993. Reflection: a review of the literature. Journal of Advanced Nursing 18(8):1188-1192. http:// dx.doi.org/10.1046/j.1365-2648.1993.18081188.x

Bàrberi, P. 2002. Weed management in organic agriculture: Are we addressing the right issues? Weed Research 42(3):177-193. http://dx.doi.org/10.1046/j.1365-3180.2002.00277.x
Beck, U., W. Bonss, and C. Lau. 2003. The theory of reflexive modernization: problematic, hypotheses and research programme. Theory, Culture \& Society 20(2):1-33. http://dx.doi. org/10.1177/0263276403020002001

Binder, C. R., A. G. Feola, and J. K. Steinberger. 2010. Considering the normative, systemic and procedural dimensions in indicator-based sustainability assessments in agriculture. Environmental Impact Assessment Review 30(2):71-81. http://dx. doi.org/10.1016/j.eiar.2009.06.002

Birks, S. 2002. Organic certification is proving too stressful. Food Manufacture 77(1):5.

Bohmann, J. 1996. Public deliberation pluralism, complexity and democracy. MIT Press, Cambridge, Massachusetts, USA.

Bolton, G. 2010. Reflective practice: writing and professional development. Sage Publications, London, UK.

Briz, T., and R. W. Ward. 2009. Consumer awareness of organic products in Spain: an application of multinominal logit models. Food Policy 34(3):295-304. http://dx.doi.org/10.1016/j. foodpol.2008.11.004

Browne, A. W., P. J. C. Harris, A. H. Hofny-Collins, N. Pasiecznik, and R. R. Wallace. 2000. Organic production and ethical trade: definition, practice and links. Food Policy 25(1):69-89. http://dx. doi.org/10.1016/S0306-9192(99)00075-5

Bulkeley, H. 2005. Reconfiguring environmental governance: towards a politics of scales and networks. Political Geography 24 (8):875-902. http://dx.doi.org/10.1016/j.polgeo.2005.07.002

Capurro, R. 1993. Zur Frage der professionellen Ethik. In P. Schefe, H. Hastedt, Y. Dittrich, and G. K. Hrsg, editors. Informatik und philosophie. Mannheim, Germany.

Chang, E., T. Dillon, and F. K. Hussain. 2006. Trust and reputation for service-oriented environments: technologies for building business intelligence and consumer confidence. John Wiley \& Sons. http://dx.doi.org/10.1002/9780470028261

Clifford, J. 1986. Introduction: partial truths. In J. Clifford and G. Marcus, editors. Writing culture: the poetics and politics of ethnography. University of California Press, Berkeley, California, USA.

Cohen, N. E., M. A. van Asseldonk, and E. N. Stassen. 2007. Social-ethical issues concerning the control strategy of animal diseases in the European Union: a survey. Agriculture and Human Values 24(4):499-510. http://dx.doi.org/10.1007/s10460-007-9086-9

Cunliffe, A. L. 2003. Reflexive inquiry in organizational research: questions and possibilities. Human Relations 56(8):983-1003. http://dx.doi.org/10.1177/00187267030568004

D'Cruz, H., P. Gillingham, and S. Melendez. 2007. Reflexivity, its meanings and relevance for social work: a critical review of the literature. British Journal of Social Work 37(1):73-90. http://dx. doi.org/10.1093/bjsw/bcl001

Darnhofer, I., T. Lindenthal, R. Bartel-Kratochvil, and W. Zollitsch. 2009. Conventionalisation of organic farming practices: from structural criteria towards an assessment based on organic principles. A review. Agronomy for Sustainable Development 30(1):67-81. http://dx.doi.org/10.1051/agro/2009011 
Delgado-Ballester, E., J. L. Munuera-Aleman, and M. J. YagueGuillen. 2003. Development and validation of a brand trust scale. International Journal of Market Research 45(1):35-54.

Demiryurek, K. 2010. Analysis of information systems and communication networks for organic and conventional hazelnut producers in the Samsun province of Turkey. Agricultural Systems 103(7):444-452. http://dx.doi.org/10.1016/j.agsy.2010.04.002

DuPuis, E. M., D. Goodman, and J. Harrison. 2006. Just values or just value? Remaking the local in agro-food studies. Research in Rural Sociology and Development 12:241-268. http://dx.doi. org/10.1016/S1057-1922(06)12010-7

Fay, B. 1987. Critical social science: liberation and its limits. Cornell University Press, Ithaca, New York, USA.

Finnveden, G., M. Z. Hauschild, T. Ekvall, J. Guinée, R. Heijungs, S. Hellweg, A. Koehler, D. Pennington, and S. Suh. 2009. Recent developments in life cycle assessment. Journal of Environmental Management 91(1):1-21. http://dx.doi.org/10.1016/j.jenvman.2009.06.018

Folke, C., T. Hahn, P. Olsson, and J. Norberg. 2005. Adaptive governance of social-ecological systems. Annual Review of Environment and Resources 30:441-473. http://dx.doi.org/10.1146/ annurev.energy.30.050504.144511

Fook, J. 2002. Theorizing from practice: towards an inclusive approach for social work research. Qualitative Social Work 1 (1):79-95. http://dx.doi.org/10.1177/147332500200100106

Forrester, J. W. 1994. System dynamics, systems thinking, and soft OR. System Dynamics Review 10(2-3):245-256. http://dx.doi. org/10.1002/sdr.4260100211

Freshwater, D., and G. Rolfe. 2001. Critical reflexivity: a politically and ethically engaged research method for nursing. Nursing Times Research 6(1):526-537. http://dx.doi. org/10.1177/136140960100600109

Fritz, M., and C. Fischer. 2007. The role of trust in European food chains: theory and empirical findings. International Food and Agribusiness Management Review 10(2):141-163.

Fritz, M., and G. Schiefer. 2008. Food chain management for sustainable food system development: a European research agenda. Agribusiness 24(4):440-452. http://dx.doi.org/10.1002/ agr.20172

Giffin, K. 1967. The contribution of studies of source credibility to a theory of interpersonal trust in the communication process. Psychological Bulletin 68(2):104-120. http://dx.doi.org/10.1037/ $\underline{\mathrm{h} 0024833}$

Goodman, D. 2002. Rethinking food production-consumption: integrative perspectives. Sociologia Ruralis 42(4):271-277. http:// dx.doi.org/10.1111/1467-9523.00216

Greenwood, J. 1998. The role of reflection in single and double loop learning. Journal of Advanced Nursing 27(5):1048-1053.

Guillemin, M., and L. Gillam. 2004. Ethics, reflexivity, and "ethically important moments" in research. Qualitative Inquiry 10(2):261-280. http://dx.doi.org/10.1177/1077800403262360

Guthman, J. 2002. Commodified meanings, meaningful commodities: re-thinking production-consumption links through the organic system of provision. Sociologia Ruralis 42(4):295-311. http://dx.doi.org/10.1111/1467-9523.00218

Guthman, J. 2003. Fast food/organic food: reflexive tastes and the making of 'yuppie chow'. Social \& Cultural Geography 4 (1):45-58. http://dx.doi.org/10.1080/1464936032000049306

Hajer, M. A. 1996. Ecological modernisation as cultural politics. In S. Lash, B. Szerszynski, and B. Wynne, editors. Risk, environment and modernity: towards a new ecology. Sage Publications Ltd. http://dx.doi.org/10.4135/9781446221983.n12

Hansen, B., H. F. Alrøe, and E. S. Kristensen. 2001. Approaches to assess the environmental impact of organic farming with particular regard to Denmark. Agriculture, Ecosystems \& Environment 83(1):11-26. http://dx.doi.org/10.1016/S0167-8809 (00)00257-7

Hansen, B., E. S. Kristensen, R. Grant, H. Høgh-Jensen, S. E. Simmelsgaard, and J. E. Olesen. 2000. Nitrogen leaching from conventional versus organic farming systems - a systems modelling approach. European Journal of Agronomy 13(1):65-82. http://dx.doi.org/10.1016/S1161-0301(00)00060-5

Hatanaka, M., C. Bain, and L. Busch. 2005. Third-party certification in the global agrifood system. Food Policy 30(3):354 369. http://dx.doi.org/10.1016/j.foodpol.2005.05.006

Hertz, R. 1997. Introduction: reflexivity and voice. Pages vi-xviii in R. Hertz, editor. Reflexivity and voice. Sage Publications, Thousand Oaks, California, USA.

Hinrichs, C. C. 2003. The practice and politics of food system localization. Journal of Rural Studies 19(1):33-45. http://dx.doi. org/10.1016/S0743-0167(02)00040-2

Hjelmar, U. 2011. Consumers' purchase of organic food products. A matter of convenience and reflexive practices. Appetite 56 (2):336-344. http://dx.doi.org/10.1016/j.appet.2010.12.019

Hoegl, M., and K. P. Parboteeah. 2006. Team reflexivity in innovative projects. $R \& D$ Management $36(2): 113-125$. http://dx. doi.org/10.1111/j.1467-9310.2006.00420.x

International Federation of Organic Agriculture Movements (IFOAM). 2009. Principles of organic agriculture. [online] URL: http://www.ifoam.org/about_ifoam/principles/index.html

Jacobson, S. K., K. E. Sieving, G. A. Jones, and A. Van Doorn. 2003. Assessment of farmer attitudes and behavioral intentions toward bird conservation on organic and conventional Florida farms. Conservation Biology 17(2):595-606. http://dx.doi. org/10.1046/j.1523-1739.2003.01472.X

Jahn, G., M. Schramm, and A. Spiller. 2005. The reliability of certification: quality labels as a consumer policy tool. Journal of Consumer Policy 28(1):53-73. http://dx.doi.org/10.1007/s10603-004-7298-6

Jalava, J. 2003. From norms to trust. The Luhmannian connections between trust and system. European Journal of Social Theory 6(2):173-190.

Janssen, M., and U. Hamm. 2011. Consumer perception of different organic certification schemes in five European countries. Organic Agriculture 1(1):31-43. http://dx.doi.org/10.1007/ $\underline{\mathrm{s} 13165-010-0003-\mathrm{y}}$ 
Jarosz, L. 2000. Understanding agri-food networks as social relations. Agriculture and Human Values 17(3):279-283. http://dx. doi.org/10.1023/A:1007692303118

Jenkins, R. 1992. Pierre Bourdieu. Routledge Kegan Paul, London, UK.

Källander, I. 2008. Participatory guarantee systems-PGS. Swedish Society for Nature Conservation. [online] URL: http:// www.ifoam.org/sites/default/files/page/files/pgsstudybyssnc 2008. pdf

Kaltoft, P. 1999. Values about nature in organic farming practice and knowledge. Sociologia Ruralis 39(1):39-53. http://dx.doi. org/10.1111/1467-9523.00092

Kastberg, P. 2012. Knowledge communication theory revisitedfrom 'communication' to 'communis esse'. Paper for 10th European IFSA symposium: Producing and reproducing farming systems: new modes for sustainable food systems of tomorrow. Aarhus, Denmark.

Kember, D., D. Y. P. Leung, A. Jones, A. Y. Loke, J. McKay, K. Sinclair, H. Tse, C. Webb, F. K. Y. Wong, M. Wong, and E. Yeung. 2000. Development of a questionnaire to measure the level of reflective thinking. Assessment \& Evaluation in Higher Education 25(4):381-395. http://dx.doi.org/10.1080/713611442

King, P. M., and K. S. Kitchener. 1994. Developing reflective judgment: understanding and promoting intellectual growth and critical thinking in adolescents and adults. Jossey-Bass Publishers, San Francisco, California, USA.

Kobayashi, A. 2003. GPC ten years on: is self-reflexivity enough? Gender, Place \& Culture 10(4):345-349. http://dx.doi. org/10.1080/0966369032000153313

Kooiman, J., and M. van Vliet. 1993. Governance and public management. Managing Public Organizations.

Læssøe, J., A. Ljungdalh, P. Kastberg, E. Noe, H. F. Alrøe, T. Christensen, A. Dubgaard, S. B. Olsen, and N. Kærgård. 2012. Theories on motivation and their implication for supporting communication, learning and decisionmaking in relation to organic food systems. Paper for 10th European IFSA symposium: Producing and reproducing farming systems: new modes for sustainable food systems of tomorrow. Aarhus, Denmark.

Lampkin, N., S. Fowler, A. Jackson, I. Jeffreys, M. Lobley, M. Measures, S. Padel, M. Reed, S. Roderick, and L. Woodward. 2006. Sustainability assessment for organic farming-integrating financial, environmental, social and animal welfare benchmarking. Aspects of Applied Biology 799.

Lea, E., and T. Worsley. 2005. Australians' organic food beliefs, demographics and values. British Food Journal 107(11):855-869. http://dx.doi.org/10.1108/00070700510629797

Le Heron, R. 2003. Creating food futures: reflections on food governance issues in New Zealand's agri-food sector. Journal of Rural Studies 19(1):111-125. http://dx.doi.org/10.1016/S0743-0167 (02)00042-6

Lenk, H., and G. Ropohl. 1987. Technik und Ethik. Reclam.

Leydesdorff, L. 2000. Luhmann, Habermas and the theory of communication. Systems Research and Behavioral Science 17
(3):273-288. http://dx.doi.org/10.1002/(SICI)1099-1743(200005/06) 17:3<273::AID-SRES329>3.3.CO;2-I

Lipp, A. 2007. Developing the reflexive dimension of reflection: a framework for debate. International Journal of Multiple Research Approaches 1(1):18-26. http://dx.doi.org/10.5172/ mra.455.1.1.18

Little, R., D. Maye, and B. Ilbery. 2010. Collective purchase: moving local and organic foods beyond the niche market. Environment and Planning A 42(8):1797-1813. http://dx.doi. org/10.1068/a4262

Lockie, S. 2009. Responsibility and agency within alternative food networks: assembling the "citizen consumer". Agriculture and Human Values 26(3):193-201. http://dx.doi.org/10.1007/s10460-008-9155-8

Lockie, S., and D. Halpin. 2005. The 'conventionalisation' thesis reconsidered: structural and ideological transformation of Australian organic agriculture. Sociologia Ruralis 45(4):284-307. http://dx.doi.org/10.1111/j.1467-9523.2005.00306.x

Lockie, S., K. Lyons, G. Lawrence, and K. Mummery. 2002. Eating 'green': motivations behind organic food consumption in Australia. Sociologia Ruralis 42(1):23-40. http://dx.doi. org/10.1111/1467-9523.00200

Luhmann, N. 1986. The autopsies of social systems. Sociocybernetic Paradoxes 172-192.

Luhmann, N. 1989. Vertrauen: Ein Mechanismus der Reduktion sozialer Komplexität. Stuttgart, Enke.

Luhmann, N. 1993. Communication and social order: risk: a sociological theory. Transaction Publishers, Piscataway, New Jersey, USA.

Luhmann, N. 2011. Strukturauflösung durch Interaktion. Ein analytischer Bezugsrahmen. Soziale Systeme 17 (Heft 1):3-30.

Luhmann, N., H. Davis, J. Raffan, and K. Rooney. 1979. Trust and power: two works by Niklas Luhmann. John Wiley and Sons, Chichester, UK.

Lund, V., and H. Röcklinsberg. 2001. Outlining a conception of animal welfare for organic farming systems. Journal of Agricultural and Environmental Ethics 14(4):391-424. http://dx. doi.org/10.1023/A:1013049601079

Lupton, D. 1997. Consumerism, reflexivity and the medical encounter. Social Science \& Medicine 45(3):373-381. http://dx. doi.org/10.1016/S0277-9536(96)00353-X

Luttikholt, L. W. M. 2007. Principles of organic agriculture as formulated by the International Federation of Organic Agriculture Movements. NJAS - Wageningen Journal of Life Sciences 54(4):347-360. http://dx.doi.org/10.1016/S1573-5214 (07)80008-X

Lynch, M. 2000. Against reflexivity as an academic virtue and source of privileged knowledge. Theory, Culture \& Society 17 (3):26-54. http://dx.doi.org/10.1177/02632760022051202

Lyon, S. 2006. Evaluating fair trade consumption: politics, defetishization and producer participation. International Journal of Consumer Studies 30(5):452-464. http://dx.doi.org/10.1111/ j.1470-6431.2006.00530.x 
Mason, J. 2006. Mixing methods in a qualitatively driven way. Qualitative Research 6(1):9-25. http://dx.doi.org/10.1177/14687$\underline{94106058866}$

McCarthy, T. 1978. The critical theory of Jürgen Habermas. MIT Press, Cambridge, Massachusetts, USA.

McEachern, M. G., and P. McClean. 2002. Organic purchasing motivations and attitudes: are they ethical? International Journal of Consumer Studies 26(2):85-92. http://dx.doi.org/10.1046/ j.1470-6431.2002.00199.x

Mead, G. H. 1934. Mind, self, and society: from the standpoint of a social biologist. University of Chicago Press Books. http://dx. doi.org/10.7208/chicago/9780226516608.001.0001

Meeusen, M. J. G., V. Beekman, R. P. M. De Graaff, and S. M. A. De Kroon. 2003. Organic values in two-fold. Agriculture Economics Research Institute (LEI), Wageningen University and Research Centre, The Hague.

Milling, P. 1984. System dynamics-Konzeption und Anwendung einer Systemtheorie. Osnabrück, Universtität Osnabrück, Fachbereich Wirtschaftswissenschaften.

Moldaschl, M. 2010. Was ist reflexivität? Papers and Preprints of the Department of Innovation Research and Sustainable Resource Management ( $B W L I X)$. Chemnitz University of Technology, Chemnitz, Germany.

Mondelaers, K., W. Verbeke, and G. Van Huylenbroeck. 2009. Importance of health and environment as quality traits in the buying decision of organic products. British Food Journal 111 (10):1120-1139. http://dx.doi.org/10.1108/00070700910992952

Nelson, E., L. G. Tovar, R. S. Rindermann, and M. A. G. Cruz. 2010. Participatory organic certification in Mexico: an alternative approach to maintaining the integrity of the organic label. Agriculture and Human Values 27(2):227-237. http://dx.doi. org/10.1007/s10460-009-9205-X

Noe, E., and H. Alrøe. 2006. Combining Luhmann and ActorNetwork Theory to see farm enterprises as self-organizing systems. Cybernetics \& Human Knowing 13(1):34-48.

Noe, E., and H. F. Alrøe. 2003. Farm enterprises as self-organizing systems: a new transdisciplinary framework for studying farm enterprises? International Journal of Sociology of Agriculture and Food 11(1):3-14.

Noe, E., and H. F. Alrøe. 2012. Observing farming systems: insights from social systems theory. Pages 387-403 in I. Darnhofer, D. Gibbon, and B. Dedieu, editors. Farming systems research into the 21st century: the new dynamic. Springer. http:// dx.doi.org/10.1007/978-94-007-4503-2 17

Osterman, K. F., and R. B. Kottkamp. 2004. Reflective practice for educators: professional development to improve student learning. Corwin Press, Newbury Park, California, USA.

Pacini, C., A. Wossink, G. Giesen, and R. Huirne. 2004. Ecological-economic modelling to support multi-objective policy making: a farming systems approach implemented for Tuscany. Agriculture, Ecosystems \& Environment 102(3):349-364. http://dx. doi.org/10.1016/j.agee.2003.08.010
Pacione, M. 1997. Local exchange trading systems-a rural response to the globalization of capitalism? Journal of Rural Studies 13(4):415-427. http://dx.doi.org/10.1016/S0743-0167(97) 00026-0

Padel, S. 2001. Conversion to organic farming: a typical example of the diffusion of an innovation? Sociologia Ruralis 41(1):40-61. http://dx.doi.org/10.1111/1467-9523.00169

Padel, S., and C. Foster. 2005. Exploring the gap between attitudes and behaviour: understanding why consumers buy or do not buy organic food. British Food Journal 107(8):606-625. http://dx.doi. org/10.1108/00070700510611002

Piaget, J. 1965. The moral judgment of the child. The Free Press, New York, USA.

Polanyi, M. 1962. Personal knowledge: towards a post-critical philosophy. University of Chicago Press, Chicago, Illinois, USA.

Power, M. 1994. The audit explosion. Demos, London, UK. http:// dx.doi.org/10.1093/acprof:oso/9780198296034.003.0001

Power, M. 1997. Expertise and the construction of relevance: accountants and environmental audit. Accounting, Organizations and Society 22(2):123-146. http://dx.doi.org/10.1016/S0361-3682 (96)00037-2

Raynolds, L. T. 2000. Re-embedding global agriculture: the international organic and fair trade movements. Agriculture and Human Values 17(3):297-309. http://dx.doi.org/10.1023/A:1007608805843

Raynolds, L. T. 2004. The globalization of organic agro-food networks. World Development 32(5):725-743. http://dx.doi. org/10.1016/j.worlddev.2003.11.008

Redmond, B. 2004. Reflection in action: developing reflective practice in health and social services. Ashgate Publishing, Ltd.

Renard, M.-C. 2005. Quality certification, regulation and power in fair trade. Journal of Rural Studies 21(4):419-431. http://dx. doi.org/10.1016/j.jrurstud.2005.09.002

Renting, H., T. K. Marsden, and J. Banks. 2003. Understanding alternative food networks: exploring the role of short food supply chains in rural development. Environment and Planning A 35 (3):393-411. http://dx.doi.org/10.1068/a3510

Romme, A. G. L., and A. van Witteloostuijn. 1999. Circular organizing and triple loop learning. Journal of Organizational Change Management 12(5):439-454. http://dx.doi. org/10.1108/09534819910289110

Ropohl, G. 1982. Some methodological aspects of modelling socio-technical systems. Progress in Cybernetics and Systems Research 10:525-536.

Ropohl, G. 1996. Ethik und Technikbewertung. Suhrkamp Verlag KG.

Ropohl, G. 1999. Philosophy of socio-technical systems. Society for Philosophy and Technology; digital library and archives; VirginiaTech. [online] URL: http://scholar.lib.vt.edu/ejournals/ SPT/v4 n3html/ROPOHL.html

Sage, C. 2003. Social embeddedness and relations of regard: alternative 'good food' networks in south-west Ireland. Journal 
of Rural Studies 19(1):47-60. http://dx.doi.org/10.1016/ S0743-0167(02)00044-X

Schlüns, J., and L. Voget. 2008. Das Inklusionsproblem und seine verschiedenen Lösungsansätze. Forum Geoökology 19(1):12-16.

Schmid, O. 2010. Organic standards for the future-guidelines/ signposts rather than rules. The Organic Standard 10613-10616.

Schön, D. A. 1983. The reflective practitioner: how professionals think in action. Basic Books, New York, New York, USA.

Scott, B. 2004. Second-order cybernetics: an historical introduction. Kybernetes 33(9/10):1365-1378. http://dx.doi. org/10.1108/03684920410556007

Seyfang, G. 2006. Ecological citizenship and sustainable consumption: examining local organic food networks. Journal of Rural Studies 22(4):383-395. http://dx.doi.org/10.1016/j. jrurstud.2006.01.003

Siderer, Y., A. Maquet, and E. Anklam. 2005. Need for research to support consumer confidence in the growing organic food market. Trends in Food Science \& Technology 16(8):332-343. http://dx.doi.org/10.1016/j.tifs.2005.02.001

Smeltzer, L. R. 1997. The meaning and origin of trust in buyersupplier relationships. Journal of Supply Chain Management 33 (4):40-48. http://dx.doi.org/10.1111/j.1745-493X.1997.tb00024. $\underline{\mathrm{X}}$

Stirling, A. 2006. Precaution, foresight and sustainability: reflection and reflexivity in the governance of science and technology. In J. P. Voss, D. Bauknecht, and R. Kemp, editors. Reflexive governance for sustainable development. Edward Elgar Publishing, Northampton, Massachusetts, USA. http://dx.doi. org/10.4337/9781847200266.00020

Sultana, F. 2007. Reflexivity, positionality and participatory ethics: negotiating fieldwork dilemmas in international research. ACME: An International E-Journal for Critical Geographies 6 (3):374-385.

Synnott, M. 2013. Reflection and double loop learning the case of HS2. Teaching Public Administration 31(1):124-134.

Toke, D., and S. Raghavan. 2010. Ecological modernisation as bureaucracy - organic food and its certification in the UK and India. International Journal of Green Economics 4(3):313-326. http://dx.doi.org/10.1504/IJGE.2010.037531

Tomm, K. 1987. Interventive interviewing: Part II. Reflexive questioning as a means to enable self-healing. Family Process 26 (2):167-183. http://dx.doi.org/10.1111/j.1545-5300.1987.00167.x

Torjusen, H., G. Lieblein, M. Wandel, and C. A. Francis. 2001. Food system orientation and quality perception among consumers and producers of organic food in Hedmark County, Norway. Food Quality and Preference 12(3):207-216. http://dx. doi.org/10.1016/S0950-3293(00)00047-1

Ulrich, H. 1970. Die Unternehmung als produktives soziales System: Grundlagen der allgemeinen Unternehmungslehre, . Paul Haupt, Bern.
Ulrich, H., and G. Probst. 1991. Anleitung zum ganzheitlichen Denken und Handeln Ein Brevier fur Führungskräfte 3 Auflage. Haupt Verlag, Bern.

Ulrich, H., and G. J. B. Probst. 2001. Anleitung zum ganzheitlichen Denken und Handeln: ein Brevier für Führungskräfte. Paul Haupt, Bern.

Verhoef, P. C. 2005. Explaining purchases of organic meat by Dutch consumers. European Review of Agricultural Economics 32 (2):245-267. http://dx.doi.org/10.1093/eurrag/jbi008

Verhoog, H., M. Matze, E. L. van Bueren, and T. Baars. 2003. The role of the concept of the natural (naturalness) in organic farming. Journal of Agricultural and Environmental Ethics 16 (1):29-49. http://dx.doi.org/10.1023/A:1021714632012

Voß, J.-P., and R. Kemp. 2006. Sustainability and reflexive governance: introduction. In J. P. Vo, D. Bauknecht, and R. Kemp, editors. Reflexive governance for sustainable development. Edward Elgar Publishing, Cheltenham, Northampton, UK.

Vogl, C., L. Kilcher, and H. Schmidt. 2005. Are standards and regulations of organic farming moving away from small farmers' knowledge? Journal of Sustainable Agriculture 26(1):5-26. http:// dx.doi.org/10.1300/J064v26n01 03

Von Bertalanffy, L. 1950. An outline of general system theory. British Journal for the Philosophy of Science 1(2):134-165. http:// dx.doi.org/10.1093/bjps/I.2.134

Vos, T. 2000. Visions of the middle landscape: organic farming and the politics of nature. Agriculture and Human Values 17 (3):245-256. http://dx.doi.org/10.1023/A:1007623832251

White, S., J. Fook, and F. Gardner. 2006. Critical reflection in health and social care. McGraw-Hill International.

Wildemeersch, D., T. Jansen, J. Vandenabeele, and M. Jans. 1998. Social learning: a new perspective on learning in participatory systems. Studies in Continuing Education 20(2):251-265. http:// dx.doi.org/10.1080/0158037980200210

Yiridoe, E. K., S. Bonti-Ankomah, and R. C. Martin. 2005. Comparison of consumer perceptions and preference toward organic versus conventionally produced foods: a review and update of the literature. Renewable Agriculture and Food Systems 20(4):193-205. http://dx.doi.org/10.1079/RAF2005113

${ }^{[1]}$ Tomm uses the term self-reflexivity instead of self-reflectivity; however, in the way he discussed the term, it is how we use the term self-reflectivity. 